\title{
The influence of site tree selection method on site index determination and yield prediction in black spruce stands in northeastern Québec
}

\author{
by Daniel Mailly ${ }^{1,2}$, Sylvain Turbis ${ }^{1}$, Isabelle Auger ${ }^{1}$ and David Pothier ${ }^{3}$
}

Site index is a common and convenient indicator of forest site productivity. The concept is well suited for growth and yield predictions, although there appears to be no universal consensus on the type or number of site trees needed for its application. We compared four methods for assessing site quality using data from black spruce (Picea mariana (Mill.) BSP) stands of northeastern Québec. Data were analysed with a univariate repeated measures analysis of variance design using the MIXED procedure of the SAS system. Significant differences were found between the method based on the mean height of the 100 largest trees per hectare and three other methods that calculate site index using information from average site trees (codominants and dominants) and an equation to estimate top height from stand level data. We concur with many others that using the mean height of the 100 largest trees per hectare is a more standard procedure than simple averages of codominant and dominant tree heights for site quality assessment and growth modelling. We recommend that the next yield table system developed in the province should be based on top height trees, instead of using average codominants and dominants and an equation to estimate dominant height.

Key words: site index, top height, yield table, site trees

L'indice de qualité de station (IQS) est un outil usuel et pratique pour estimer la productivité des forêts. Le concept est approprié pour les prévisions de croissance et de production, bien qu'il semble n'exister aucun consensus universel sur le type ou le nombre d'arbres nécessaires pour son utilisation. Nous avons comparé quatre méthodes pour évaluer l'IQS en utilisant des données issues de pessières noires (Picea mariana (Mill.) BSP) du nord-est québécois. Les données ont été analysées en utilisant un dispositif d'analyse de variance univariable en mesures répétées à l'aide de la procédure MIXED du progiciel SAS. Des différences significatives ont été trouvées entre la méthode basée sur la hauteur moyenne des 100 plus gros arbres à l'hectare et trois autres méthodes qui calculent l'IQS en utilisant l'information provenant d'arbres moyens et une équation estimant la hauteur dominante à partir des données du peuplement. Nous concluons qu'il n'est pas recommandé d'utiliser la méthode basée sur la taille moyenne des 100 plus gros arbres à l'hectare dans un système de tables de production mis au point avec les données d'arbres moyens, sans encourir le risque d'obtenir des estimations biaisées. Nous sommes d'avis avec d'autres que l'utilisation de la méthode basée sur la taille moyenne des 100 plus gros arbres à l'hectare est préférable à la méthode de la moyenne des arbres codominants et dominants pour l'estimation de l'IQS et la modélisation de la croissance des arbres. Nous proposons que le prochain système de tables de production qui sera mis au point dans la province soit basé sur les 100 plus gros arbres à l'hectare, en remplacement de la méthode utilisant la moyenne des codominants et dominants et une équation pour estimer la hauteur dominante.

Mots clés : indice de qualité de station, hauteur dominante, table de production, arbres-échantillons

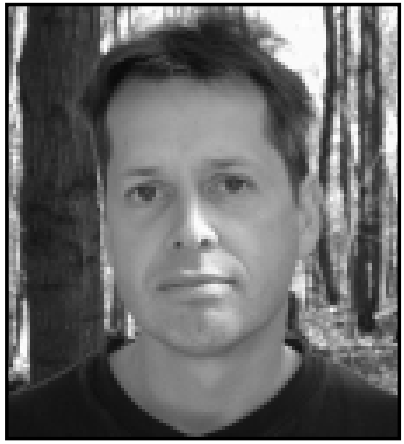

Daniel Mailly

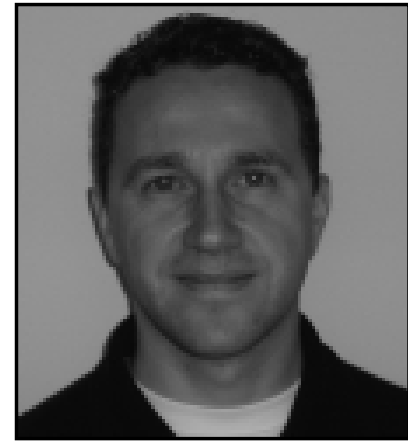

Sylvain Turbis

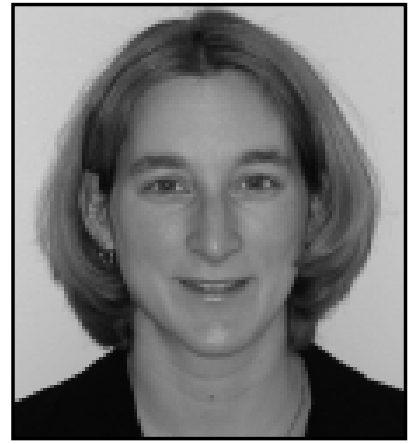

Isabelle Auger

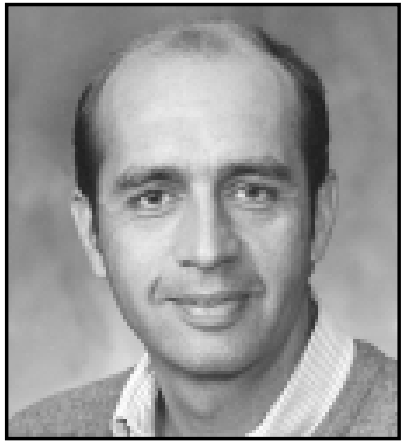

David Pothier

\section{Introduction}

Site index, the height of selected site trees at some reference age, is a common and convenient indicator of forest site productivity (Zeide and Zakrzewski 1993, Garcia 1998). The con-

cept is well suited for growth and yield predictions and silvicultural prescriptions (Magnussen 1999), although there appears to be no universal consensus on the type or number of site trees needed for its application (McRoberts 1996). A common practice

\footnotetext{
${ }^{1}$ Direction de la recherche forestière, Ministère des Ressources naturelles, de la Faune et des Parcs, 2700, rue Einstein, Sainte-Foy, Québec G1P 3W8.

${ }^{2}$ Author to whom all correspondence should be addressed. E-mail: daniel.mailly@ mrnfp.gouv.qc.ca

${ }^{3}$ Present address: Faculté de foresterie et géomatique, Université Laval, Cité Universitaire, Sainte-Foy, Québec G1K 7P4.
} 
usually involves the random selection of dominant and codominant trees, followed by measurement of these trees for total height and age (Clutter et al. 1983). The average height of the 100 largest (diameter) trees per hectare or top height is often used in Europe (Hägglund 1981) or in North America (e.g., Forest Productivity Council of British Columbia 1998). Moreover, these two methods are sometimes applied interchangeably, as is the case when only dominant trees are used with site curves constructed from both dominant and codominant tree data (Ker 1952, Carmean 1975).

Choosing the sample trees for determining stand height and age is an important decision when developing and applying site index equations (Lloyd and Hafley 1977, Pienaar and Shiver 1984). Typically, site trees should be selected carefully and should not have suffered from suppression, defoliation, or top damage since they are expected to have been in the upper crown canopy throughout their life (Monserud 1985, Nigh and Love 1999). Obtaining the average height of selected dominants and codominants is generally a convenient and quick task and precise estimates of site index have been obtained using this method, especially when the same trees are used at each measurement (Sharma et al. 2002). This tree selection process is somewhat subjective, however, and some inconsistency among samplers may be encountered (Clutter et al. 1983, Nicholas et al. 1991). Conversely, dominants are less variable in height than are dominants and codominants combined, and therefore fewer dominant trees are needed to attain a specified level of accuracy (Carmean 1975). When study trees are selected among codominants and dominants, as is the case in Quebec (Ministère des Ressources naturelles du Québec 1998), top height can be predicted using a relationship that adjusts the height of study trees with a function involving the diameter of both the sample trees and of the four largest trees per plot (Pothier and Savard 1998). This note reports on a comparison between four different methods for calculating site index from selected site trees and on the importance of site tree selection for site index determination and yield prediction in black spruce stands in Northeastern Québec. In particular, we wanted to test the impact of using measured top height trees in a yield prediction system based on average codominant and dominant trees.

\section{Materials and Methods}

Data from another project (J.-P. Carpentier, personal communication) provided the necessary material for conducting the present study. Between 1997 and 1999, inventory plots were established in various black spruce (Picea mariana (Mill.) BSP)dominated stands in an area that belongs to the Balsam FirWhite Birch bioclimatic domain (Robitaille and Saucier 1998). The stands, which were located in Northeastern Québec, originated either from clear-cutting or from old horse-logging and were between 29 and 125 years of age on average (Table 1). The study was conducted at six different locations and within each location, six independent $400 \mathrm{~m}^{2}$ circular sample plots were established for a total of 36 plots. All trees with a merchantable diameter outside bark at breast height $\left(D_{130}\right.$, height $=130 \mathrm{~cm}$, Brokaw and Thompson 2000) greater than $9.0 \mathrm{~cm}$ within each sample plot were inventoried. Total height and $\mathrm{D}_{130}$ were measured, and age was determined by taking one or two increment cores at $1 \mathrm{~m}$ height for all merchantable trees. A total of 2203 trees were thus cored for age determination at $1 \mathrm{~m}$ in this study, an average of 61 trees per
0.04 ha plot. Each tree was also assigned a canopy class (dominant, codominant, intermediate, suppressed). Saplings $\left(1.0<\mathrm{D}_{130} \leq 9.0 \mathrm{~cm}\right)$ were tallied in one $40 \mathrm{~m}^{2}$ subplot, located in the center of the plot. Veterans or highly suppressed trees were inventoried but excluded from the site index calculations. A tree was considered a veteran if its age was more than twice the average plot age. Plot basal area was calculated using merchantable and non-merchantable trees and plot volume was calculated by using Perron (1983)'s tariff tables (Table 1).

For each plot, dominant height $\left(H_{d}\right)$, age $(A g e)$, site index $(S I)$, rotation age $(R A)$ and volume at rotation age $\left(V_{R A}\right)$ were calculated and used as variables of interest. Site index (height at reference age 50 years, taken at $1 \mathrm{~m}$ ) was calculated according to four different methods using a black spruce site index equation developed for the entire province of Québec (Pothier and Savard 1998):

$$
S I=0.9604 \cdot H_{d}^{0.9412}\left(1-e^{-0.03379 \cdot A}\right)^{-0.697 \cdot H_{d} 0.1046}
$$

where $H_{d}$ is dominant height (m) and $A$ is age of site trees at $1 \mathrm{~m}$ height (standard height for age determination in Québec). Four different methods of calculating plot site index were compared in this study. For the first three methods, site index was computed using information from average site trees (i.e., codominants and dominants) and an equation to estimate top height from stand level data (Bégin and Raulier 1995, Pothier and Savard 1998) that is then used as an input to Equation 1:

$$
H_{d, e s t}=1.3+\left[\frac{\bar{D}_{4}}{\left(\frac{\bar{D}}{\bar{H}-1.3}\right)+0.0349 \cdot\left(\bar{D}_{4}-\bar{D}\right)}\right]
$$

where $H_{\text {dest }}$ is the estimated dominant height (m), $\bar{D}_{4}$ is the average $D_{130}$ of the four largest black spruce trees per plot, $\bar{D}$ and $H$ are the average $\mathrm{D}_{130}$ and height of selected site trees, respectively.

The first method, hereafter referred to as $T P$, is based on site trees measured in temporary plots and is the method currently in use in the province of Quebec. With this method, $H_{d}$ was estimated using Equation 2 and the arithmetic mean of the height and diameter of three site trees following the procedures for temporary sample plots in Québec (Ministère des Ressources naturelles du Québec 2001a). According to these procedures, site trees must i) be selected close to the plot center, ii) have a $D_{130}$ close to the average $D_{130}$ of codominant and dominant trees, and iii) belong to the codominant or dominant canopy class. Since trees in the sample plots were not stem-mapped, $\mathrm{x}-\mathrm{y}$ coordinates were generated a posteriori using a uniform random number generator (Matlab ${ }^{\mathrm{TM}}$ release 11 (1999), Mathworks Inc.). The site trees were chosen following the criteria described above if their $\mathrm{D}_{130}$ was within $\pm 15 \%$ of the $\mathrm{D}_{130}$ of the median $\mathrm{D}_{130}$ tree.

For the second method, hereafter referred to as $P P, H_{d}$ was estimated using Equation 2 and the arithmetic mean of the height and diameter of up to nine site trees following the procedures for permanent sample plots in Québec (Ministère des Ressources naturelles du Québec 2001b). According to these procedures, nine trees are measured within each sample plot. Four site trees 


\begin{tabular}{|c|c|c|c|c|c|}
\hline Plot number & $\begin{array}{c}\text { Density } \\
\left(\text { stems ha }^{-1}\right)\end{array}$ & $\begin{array}{l}\text { Total basal area } \\
\left(\mathrm{m}^{2} \mathrm{ha}^{-1}\right)\end{array}$ & $\begin{array}{l}\text { Total volume } \\
\left(\mathrm{m}^{3} \mathrm{ha}^{-1}\right)\end{array}$ & $\begin{array}{c}\text { Age at } 1 \mathrm{~m} \\
\text { height (years) }\end{array}$ & $\begin{array}{c}\text { Top height } \\
(\mathrm{m})\end{array}$ \\
\hline Site 1 & $49^{\circ} 10^{\prime} \mathrm{N}$ & $68^{\circ} 30^{\prime} \mathrm{W}$ & & & \\
\hline 1 & 5425 & 27.1 & 85.3 & 65 & 12.2 \\
\hline 2 & 2900 & 26.3 & 79.3 & 71 & 10.8 \\
\hline 3 & 2900 & 25.1 & 104.8 & 90 & 14.6 \\
\hline 4 & 8200 & 18.5 & 36.2 & 50 & 8.1 \\
\hline 5 & 7750 & 9.4 & 14.9 & 32 & 6.2 \\
\hline 6 & 14475 & 31.4 & 74.7 & 35 & 9.6 \\
\hline Site 2 & $49^{\circ} 13^{\prime} \mathrm{N}$ & $68^{\circ} 32^{\prime} \mathrm{W}$ & & & \\
\hline 7 & 6475 & 30.5 & 123.9 & 86 & 14.3 \\
\hline 8 & 10125 & 34.5 & 122.4 & 97 & 13.7 \\
\hline 9 & 3350 & 35.0 & 150.1 & 84 & 14.7 \\
\hline 10 & 13675 & 35.9 & 96.5 & 72 & 11.8 \\
\hline 11 & 7300 & 22.0 & 69.2 & 64 & 11.3 \\
\hline 12 & 7000 & 31.2 & 93.4 & 58 & 11.2 \\
\hline Site 3 & $49^{\circ} 48^{\prime} N$ & $68^{\circ} 50^{\prime} \mathrm{W}$ & & & \\
\hline 13 & 7775 & 50.5 & 224.5 & 70 & 15.2 \\
\hline 14 & 6275 & 50.7 & 256.6 & 93 & 17.7 \\
\hline 15 & 7450 & 37.7 & 155.5 & 81 & 14.2 \\
\hline 16 & 6500 & 25.9 & 83.6 & 69 & 12.2 \\
\hline 17 & 25950 & 43.5 & 92.7 & 29 & 10.3 \\
\hline 18 & 17000 & 40.7 & 97.9 & 36 & 10.8 \\
\hline Site 4 & $49^{\circ} 58^{\prime} N$ & $71^{\circ} 24^{\prime} W$ & & & \\
\hline 19 & 8225 & 36.9 & 158.1 & 125 & 15.8 \\
\hline 20 & 7050 & 42.3 & 157.7 & 82 & 14.1 \\
\hline 21 & 11425 & 39.4 & 128.9 & 69 & 12.3 \\
\hline 22 & 10175 & 23.8 & 55.7 & 111 & 11.2 \\
\hline 23 & 11750 & 43.0 & 123.4 & 61 & 12.2 \\
\hline 24 & 9500 & 35.6 & 102.5 & 66 & 11.6 \\
\hline Site 5 & $49^{\circ} 41^{\prime} N$ & $68^{\circ} 38^{\prime} W$ & & & \\
\hline 25 & 10825 & 36.2 & 139.2 & 52 & 11.9 \\
\hline 26 & 9350 & 42.1 & 128.2 & 57 & 12.9 \\
\hline 27 & 9150 & 40.3 & 123.4 & 60 & 13.3 \\
\hline 28 & 15150 & 34.7 & 84.7 & 43 & 10.7 \\
\hline 29 & 6100 & 30.8 & 100.7 & 46 & 11.7 \\
\hline 30 & 9850 & 36.5 & 98.7 & 55 & 12.9 \\
\hline Site 6 & $49^{\circ} 50^{\prime} \mathrm{N}$ & $68^{\circ} 50^{\prime} \mathrm{W}$ & & & \\
\hline 31 & 4150 & 32.7 & 182.7 & 86 & 19.6 \\
\hline 32 & 7350 & 39.5 & 174.7 & 97 & 16.8 \\
\hline 33 & 7325 & 46.1 & 235.5 & 106 & 20.8 \\
\hline 34 & 10000 & 36.7 & 139.2 & 111 & 14.8 \\
\hline 35 & 5025 & 24.5 & 90.6 & 83 & 13.7 \\
\hline 36 & 5425 & 29.9 & 116.6 & 88 & 15.4 \\
\hline
\end{tabular}

are chosen following the same method as the one used for temporary sample plots, except that four trees instead of three are selected. Five additional trees are systematically chosen based on their rank, i.e., the total number of merchantable trees is divided by five, and the quotient is multiplied by 1,2, 3, 4 and 5 to give the tree tag number that will be measured. For the purpose of this study, all nine site trees measured in this case were used for site index determination. For the third method, hereafter referred to as $C D, H_{d}$ was estimated using Equation 2 and the arithmetic mean of the height and diameter of all trees belonging to the dominant and codominant canopy classes.

The last method, hereafter referred to as $D M$, is based on top height, i.e., the height of the largest diameter tree on a 0.01-ha plot, providing the tree is suitable for measurement (Forest Productivity Council of British Columbia 1998). For this method, $H_{d}$ is calculated as the arithmetic mean of the measured height of the four largest dominant black spruce trees per 0.04-ha plot.
For each plot, the rotation age was determined as the age corresponding to the maximum mean annual increment (Clutter et al. 1983) using a computerized version of Pothier and Savard (1998)'s system of equations (Turbis et al. 2002). The predicted merchantable volume at rotation age was calculated using Equation 3:

$$
\text { Vol }=0.38188 \cdot H_{d}^{0.99964} G^{0.88767} \bar{D}_{q}^{0.06724}
$$

where $H_{d}$ is dominant height (m), $G$ is the plot merchantable basal area $\left(\mathrm{m}^{2} \mathrm{ha}^{-1}\right)$ and $D$ is the quadratic mean diameter $(\mathrm{cm})$ of merchantable trees (Pothier and Savard 1998).

Data were analysed using a univariate repeated measures analysis of variance. The site index estimation method (treatment) is the repeated effect since the four methods are all measured on the same plot. In order to model the correlation between methods from the same plot, the MIXED procedure of the SAS system was used and the covariance structure 
Table 2. Results of the univariate repeated measures analysis of variance performed on the data for five dependent variables to test the variation due to the site index determination method using SAS PROC MIXED

\begin{tabular}{|c|c|c|c|c|c|c|}
\hline Variable & $\begin{array}{c}\text { Site index } \\
\text { determination method }\end{array}$ & Mean & SE & df & $F$ & $P$ \\
\hline \multirow[t]{4}{*}{ Dominant height $\left(\mathrm{H}_{d}, \mathrm{~m}\right)$} & $\mathrm{CD}$ & 13.32 & 0.541 & 135 & 6.3 & 0.001 \\
\hline & PP & 13.09 & 0.530 & & & \\
\hline & $\mathrm{TP}$ & 13.12 & 0.555 & & & \\
\hline & DM & 13.07 & 0.578 & & & \\
\hline \multirow[t]{4}{*}{ Age (years) } & $\mathrm{CD}$ & 63.4 & 4.28 & 135 & 11.4 & 0.000 \\
\hline & PP & 60.6 & 4.15 & & & \\
\hline & $\mathrm{TP}$ & 62.8 & 4.62 & & & \\
\hline & DM & 71.5 & 4.81 & & & \\
\hline \multirow[t]{4}{*}{ Site Index (SI, m) } & $\mathrm{CD}$ & 12.59 & 0.525 & 135 & 7.1 & 0.000 \\
\hline & PP & 12.55 & 0.531 & & & \\
\hline & TP & 12.52 & 0.537 & & & \\
\hline & DM & 12.02 & 0.529 & & & \\
\hline \multirow[t]{4}{*}{ Rotation Age ( $R A$, years) } & CD & 58.6 & 2.75 & 135 & 16.1 & 0.000 \\
\hline & PP & 57.8 & 2.63 & & & \\
\hline & $\mathrm{TP}$ & 58.6 & 2.77 & & & \\
\hline & $\mathrm{DM}$ & 61.7 & 2.83 & & & \\
\hline \multirow{4}{*}{$\begin{array}{l}\text { Volume at rotation age } \\
\left(\mathrm{V}_{R A}, \mathrm{~m}^{3} \mathrm{ha}^{-1}\right)\end{array}$} & & & & & & $0 \Omega \cap 0$ \\
\hline & $\begin{array}{l}\mathrm{CD} \\
\mathrm{PP}\end{array}$ & 96.2 & 7.30 & 135 & 8.5 & 0.000 \\
\hline & TP & $\begin{array}{l}90.2 \\
95.0\end{array}$ & $\begin{array}{l}1.36 \\
7.40\end{array}$ & & & \\
\hline & $\mathrm{DM}$ & 88.1 & 7.28 & & & \\
\hline
\end{tabular}

Notes: site index determination methods: CD, based on all codominant and dominant trees; PP, based on procedures for permanent sample plots; TP, based on procedures for temporary sample plots; DM, based on the 100 largest trees per hectare.

between methods was specified using the REPEATED statement. The unstructured covariance option was used because there was no evidence of pattern of correlation between methods. Plots were defined as the subjects or experimental units and sites were considered a random effect. Since the variance parameter Treatment $\times$ Site was estimated to be zero or near zero, it was included in the residual error term. The number of degrees of freedom (df) for testing the treatment effect was 135 ( 36 plots $\times 4$ treatments $-3 \mathrm{df}$ for treatment effect $-5 \mathrm{df}$ for site effect -1$)$. The normality assumption was not violated and the possible heterogeneity of variance between methods was accounted by the unstructured covariance matrix. Multiple comparisons between treatment effects were adjusted using Tukey-Kramer's method (SAS Institute Inc. 2000).

\section{Results}

Results from the MIXED procedure for tests of fixed effects for the site index estimation methods (treatments) indicated that these were significantly different for all five dependent variables $\left(H_{d}, A g e, S I, R A\right.$, and $V_{R A}$, Table 2$)$. The methods that estimate dominant height with Equation 2 (methods $T P, P P$ and $C D$ ) overestimated $S I$ and $V_{R A}$ and underestimated age and rotation age when compared to the method that used the four largest trees ( $D M$, Table 2). This resulted in the measured age of site trees being 8 to 11 years younger for these methods (TP, $P P$ and $C D$ ) when compared to $D M$ (Table 2).

Equation 2 was found to be effective in estimating dominant height, $C D$ and $P P$ being the only two methods with statistically different $H_{\text {d,est }}(\Delta=0.23 \mathrm{~m}, P=0.002$, Table 3$)$. Since dominant height $\left(H_{d}\right)$ was found to be fairly similar across methods whereas age yielded variable comparisons (Table 3), this resulted in $S I$ estimates significantly higher for methods based on $T P, P P$ and $C D$ when compared to $D M(\Delta=$
$0.50-0.57 \mathrm{~m}$, Table 3). For instance, the site index estimate based on the method that is commonly used in Québec for estimating site productivity $(T P, 12.5 \mathrm{~m})$ was found to be significantly higher $(>4.2 \%, P=0.03)$ than the estimate based on dominant trees only $(D M, 12.0 \mathrm{~m})$. A higher site index estimate being synonymous with higher site productivity, the use of methods $T P, P P$ and $C D$ resulted in significantly shorter rotation age estimates $(\triangle R A=3.1-3.9$ years, Table 3$)$ than for method $D M$. As a consequence, estimates of volume at rotation age were significantly higher for methods $T P, P P$ and $C D\left(\Delta V_{R A}=7.0-\right.$ $8.2 \mathrm{~m}^{3} \mathrm{ha}^{-1}$, Table 3 ) when compared to $D M$. As a comparison, the volume at rotation age based on the method that is commonly used in Québec for estimating site productivity ( $T P$, $\left.95.0 \mathrm{~m}^{3} \mathrm{ha}^{-1}\right)$ was found to be significantly higher $(>7.8 \%$, $P=0.02)$ than the estimate based on dominant trees only ( $D M$, $\left.88.1 \mathrm{~m}^{3} \mathrm{ha}^{-1}\right)$.

\section{Discussion}

The results presented in this study indicate that the selection of site trees has an impact not only on the calculation of dominant height but also on the estimation of the average age of trees used for site index determination. As stated by McQuilkin (1974), small differences in age (10-15 years) between trees used for assessing site index in the same stand may have a significant effect on the index value. In this study, three site index calculation methods ( $T P, P P$ and $C D$ ) used an equation to estimate dominant height from average site trees. However, since site trees used with these three methods were significantly younger than top height trees (method $D M$ ), this resulted in higher site index values compared to the method based on the 100 largest trees per ha. These results call into question whether it is appropriate to calculate site index from measured top height trees (method $D M$ ) in a yield prediction system based 
Table 3. Differences of least squares means between site index determination methods using SAS PROC MIXED, adjusted using Tukey-Kramer's method

\begin{tabular}{|c|c|c|c|c|c|}
\hline Methods compared & Difference & SE & Adjusted Lower & Adjusted Upper & Adjusted $P$ \\
\hline \multicolumn{6}{|l|}{ Dominant height $(m)$} \\
\hline CD-PP & 0.23 & 0.064 & 0.07 & 0.40 & 0.002 \\
\hline CD-TP & 0.20 & 0.116 & -0.10 & 0.50 & 0.323 \\
\hline CD-DM & 0.25 & 0.138 & -0.11 & 0.61 & 0.278 \\
\hline PP-TP & -0.03 & 0.090 & -0.27 & 0.20 & 0.983 \\
\hline PP-DM & 0.02 & 0.157 & -0.39 & 0.42 & 1.000 \\
\hline TP-DM & 0.05 & 0.175 & -0.40 & 0.51 & 0.992 \\
\hline \multicolumn{6}{|l|}{ Age (years) } \\
\hline CD-PP & 2.87 & 0.899 & 0.53 & 5.21 & 0.009 \\
\hline CD-TP & 0.67 & 1.517 & -3.27 & 4.62 & 0.971 \\
\hline CD-DM & -8.11 & 1.507 & -12.03 & -4.19 & $<0.001$ \\
\hline PP-TP & -2.20 & 1.541 & -6.21 & 1.81 & 0.486 \\
\hline PP-DM & -10.98 & 1.979 & -16.13 & -5.83 & $<0.001$ \\
\hline TP-DM & -8.78 & 2.445 & -15.14 & -2.42 & 0.003 \\
\hline \multicolumn{6}{|l|}{ Site Index (m) } \\
\hline CD-PP & 0.04 & 0.075 & -0.16 & 0.23 & 0.956 \\
\hline CD-TP & 0.07 & 0.119 & -0.24 & 0.38 & 0.942 \\
\hline CD-DM & 0.57 & 0.136 & 0.21 & 0.92 & $<0.001$ \\
\hline PP-TP & 0.03 & 0.106 & -0.25 & 0.30 & 0.993 \\
\hline PP-DM & 0.53 & 0.174 & 0.07 & 0.98 & 0.012 \\
\hline TP-DM & 0.50 & 0.178 & 0.03 & 0.96 & 0.030 \\
\hline \multicolumn{6}{|l|}{ Rotation age (years) } \\
\hline CD-PP & 0.75 & 0.395 & -0.28 & 1.78 & 0.234 \\
\hline CD-TP & -0.06 & 0.586 & -1.58 & 1.47 & 1.000 \\
\hline CD-DM & -3.14 & 0.456 & -4.33 & -1.95 & $<0.001$ \\
\hline PP-TP & -0.81 & 0.632 & -2.45 & 0.84 & 0.581 \\
\hline PP-DM & -3.89 & 0.679 & -5.66 & -2.12 & $<0.001$ \\
\hline TP-DM & -3.08 & 0.787 & -5.13 & -1.04 & 0.001 \\
\hline \multicolumn{6}{|c|}{ Volume at rotation age $\left(m^{3} \mathrm{ha}^{-1}\right)$} \\
\hline CD-PP & 0.00 & 0.987 & -2.57 & 2.57 & 1.000 \\
\hline CD-TP & 1.19 & 1.530 & -2.78 & 5.17 & 0.863 \\
\hline CD-DM & 8.17 & 1.696 & 3.76 & 12.58 & $<0.001$ \\
\hline PP-TP & 1.19 & 1.353 & -2.32 & 4.71 & 0.814 \\
\hline PP-DM & 8.17 & 2.193 & 2.46 & 13.87 & 0.002 \\
\hline TP-DM & 6.97 & 2.373 & 0.80 & 13.15 & 0.020 \\
\hline
\end{tabular}

Note: SE = standard error of estimate; Site index determination methods: CD, based on all codominant and dominant trees; PP, based on procedures for permanent sample plots; TP, based on procedures for temporary sample plots; DM, based on the 100 largest trees per hectare.

on an equation to estimate dominant height from three average site trees (codominants and dominants; method $T P$ ).

On the one hand, selecting dominant trees is often preferred over average codominants and dominants because it is assumed that the height growth of dominant trees is affected less by differences in stand density than that of trees in lower crown classes (Pienaar and Shiver 1984, MacFarlane et al. 2000). Also, because dominants are less variable in height than are dominants and codominants combined, fewer dominant trees are needed to attain a specified level of accuracy (Ker 1952, Carmean 1975). On the other hand, the average height of selected codominants and dominants can be obtained with a minimum amount of time spent on selection of sample trees (Clutter et al. 1983). Using such trees also has the advantage of concomitantly providing additional and valuable data for fitting height-diameter curves when such data are needed. Surprisingly, no difference was found in site index estimates between the three methods that used an equation to estimate dominant height from average site trees. This seems to indicate that differences in the number of average site trees chosen did not have a significant impact on the calculation of site index, if measurements are performed on at least three trees. Differences in age and height values between the method based on permanent sample plots $(P P)$ and the method based on all codominants and dominants trees $(C D)$ were found, however, suggesting that there is a risk of obtaining different estimates with average site trees, especially when dealing with stand structures that are not entirely homogeneous.

Although dominant tree heights are more stable and less variable than the average height of codominants and dominants (Ker 1952), top height trees are not systematically sampled in the province of Québec, which relies on an equation to estimate dominant height from average site trees. This raises the question about whether top height trees should now be operationally sampled (method $D M$ ) in lieu of average codominants and dominants with height adjustments (methods $P P$ and $T P$ ) for site index determination, even though the current yield tables are based on estimated dominant heights (Pothier and Savard 1998). Results from this study show that the use of top height trees in the application of yield tables for black 
spruce provided the lowest site index estimates among the four different methods tested. This method also yielded the highest rotation age and lowest volumes at rotation age estimates among the four different methods tested. These results are in disagreement with those of Ker (1952), who asserted that it is not necessary to use the same method of site index determination as the one employed in the construction of yield tables. Also, in cases where average site trees are younger than top height trees, it is normally expected that site index be somewhat overestimated if only top height trees are used with site index curves constructed from both codominants and dominants (Carmean 1975).

The fact that the opposite result was found in this study suggests the possibility of estimating not only dominant height but also the age of dominants if top height trees are not measured and top height is to be estimated. It is likely that fitting an equation to adjust the age of average site trees similar to the one used for estimating dominant height might have yielded site index values similar to the method with top height tree data, but this was not tested. It can be hypothesized, though, that adding another function to the process of site index determination would increase the chance of obtaining more variable estimates.

Even though the results from this study clearly demonstrate that the selection method for site trees may have a significant impact on site index determination, a few words of caution are necessary for the interpretation of our results. For example, in spite of the fact that more than 2200 trees were cored for age determination, the distribution of the 36 inventory plots was located in an area covering only $20000 \mathrm{~km}^{2}$ in northeastern Quebec. Thus, the results are applicable only to a specific portion of the distribution zone of black spruce in Quebec, and cannot be generalized yet to the whole province. Also, a site index equation (Equation 1) was used as the basis for all comparisons instead of a true site index based on stem analysis. Because this site index equation does not exactly pass through the appropriate height at reference age, a bias of approximately $+0.05 \mathrm{~m}$ for the site indices tested (between 12 and $13 \mathrm{~m}$ ) was introduced in the data analysis. This bias is ten times smaller than the average differences between methods that were significantly different ( $\mathrm{SE} \sim 0.5 \mathrm{~m}$, Table 3$)$. Also, the biases are virtually the same for all methods tested and cancel each other out when differences between methods are calculated. Finally, recent evidence suggests that site index curves based on temporary plots and permanent sample plots have comparable average bias and accuracy (Raulier et al. 2003), and that the dynamics of tree social status cast a serious doubt on the assumption of dominance stability which is often made to justify the use of stem analyses for site index curves construction.

\section{Conclusions}

We compared four different methods for assessing site quality from selected site trees from black spruce stands growing in northeastern Québec and quantified their influence on stand top height, age, site index, rotation age and volume at rotation age. A comparison between the method with the mean height of the 100 largest trees per hectare (method DM) and the method commonly in use based on temporary plots (method TP) revealed significant differences of about $-4 \%,+5 \%$ and $-8 \%$ for site index, rotation age and volume at rotation age, respectively. On the basis of these results, we conclude that it is not advisable to use the former method with a yield table system developed with the latter, without incurring the risk of obtaining systematically biased estimates.

We concur with many others that using the mean height of the 100 largest trees per hectare is a more standard procedure than simple averages of codominant and dominant tree heights for site quality assessment and growth modelling. We recommend that the next yield table system developed in the province should be based on top height trees, instead of using average codominants and dominants and an equation to estimate dominant height. It should be remembered, however, that the exact number of top height trees needed may also depend on plot size (Rennolls 1978, Pardé and Bouchon 1988, Magnussen 1999) and stand structure (Salas González et al. 1993), and that it deserves further study before it is routinely applied to black spruce stands.

\section{Acknowledgements}

The black spruce data were collected and provided by Dr. Jean-Pierre Carpentier. His assistance and that from Éric Daigle and Louis Blais from the Direction de la recherche forestière, Forêt-Québec, is gratefully acknowledged. Thanks also to Jean-Pierre Michaud and Charles Warren of AbitibiConsolidated for their help in choosing and locating the study sites. We thank Steeve Pepin and Stéphane Tremblay (Direction de la recherche forestière, Forêt-Québec) and two anonymous reviewers for helpful comments.

\section{References}

Begin, J. and F. Raulier. 1995. Comparaison de différentes approches, modèles et tailles d'échantillons pour l'établissement de relations hauteur-diamètre locales. Can. J. For. Res. 25: 1303-1312. Brokaw, N. and J. Thompson. 2000. The H for DBH. For. Ecol. Manage. 129: 89-91.

Carmean, W.H. 1975. Forest site quality evaluation in the United States. Adv. Agron. 27: 209-269.

Clutter, J.L., J.C. Fortson, L.V. Pienaar, G.H. Brister and R.L. Bailey. 1983. Timber management: a quantitative approach. John Wiley \& Sons, New York.

Forest Productivity Council of British Columbia. 1998. Definition and estimation of top height for site index. Forest Productivity Council Policy. http://www.forestproductivity.gov.bc.ca/Standards/topheight/top_height.htm

García, O. 1998. Estimating top height with variable plot sizes. Can. J. For. Res. 28: 1509-1517.

Hägglund, B. 1981. Evaluation of forest site productivity. Forestry Abstracts 42: 515-527.

Ker, J.W. 1952. An evaluation of several methods of estimating site index of immature stands. For. Chron. 28: 63-74.

Lloyd, F.T. and W.L. Hafley. 1977. Precision and the probability of misclassification in site index estimation. For. Sci. 23: 493-499. MacFarlane, D.W., E.J. Green and H.E.Burkart. 2000. Population density influences assessment and application of site index. Can. J. For. Res. 30: 1472-1475.

Magnussen, S. 1999. Effect of plot size on estimates of top height in Douglas-fir. West. J. Appl. For. 14: 17-27.

McQuilkin, R.A. 1974. Site index prediction tables for black, scarlet and white oaks in southeastern Missouri. USDA Forest Service, North Central Forest Experiment Station, Res. Pap. NC-108.

McRoberts, R.E. 1996. Estimating variation in field crew estimates of site index. Can. J. For. Res. 26: 560-565.

Ministère des Ressources naturelles du Québec. 1998. Manuel d'aménagement forestier, $3^{\mathrm{e}}$ édition. Ministère des Ressources naturelles. $122 \mathrm{p}$. 
Ministère des Ressources naturelles du Québec. 2001a. Normes d'inventaire forestier: les placettes-échantillons temporaires, peuplements de $7 \mathrm{~m}$ et plus de hauteur. Direction des inventaires forestiers, Forêt-Québec, Ministère des Ressources naturelles. 210 p.

Ministère des Ressources naturelles du Québec. 2001b. Normes d'inventaire forestier: les placettes-échantillons permanentes. Direction des inventaires forestiers, Forêt-Québec, Ministère des Ressources naturelles. $248 \mathrm{p}$

Monserud, R.A. 1985. Applying height growth and site index curves for inland Douglas-fir. USDA For. Serv., Res. Pap. INT-347. Nicholas, N.S., T.G. Gregoire and S.M. Zedaker. 1991. The reliability of tree crown position classification. Can. J. For. Res. 21: 698-701. Nigh, G.D. and B.A. Love. 1999. How well can we select undamaged site trees for estimating site index? Can. J. For. Res. 29: 1989-1992.

Pardé, J. and J. Bouchon. 1988. Dendrométrie. $2^{\mathrm{e}}$ édition. ENGREF, Nancy, 328 pp.

Perron, J.-Y. 1983. Tarif de cubage général - Volume marchand brut. Ministère de l'Énergie et des Ressources (Québec). 52 p.

Pienaar, L.V. and B.D. Shiver. 1984. The effect of planting density on dominant height in unthinned slash pine plantations. For. Sci. 30: 1059-1066.

Pothier, D. and F. Savard. 1998. Actualisation des tables de production pour les principales espèces forestières du Québec. Direction des inventaires forestiers, Ministère des Ressources naturelles du Québec.
Raulier, F., Lambert, M.-C., Pothier, D. and Ung, C.-H. 2003. Impact of dominant tree dynamics on site index curves. For. Ecol. Manage. 184: 65-78.

Rennolls, K. 1978. Top height: its definition and estimation. Commonw. For. Rev. 57: 215-219.

Robitaille, A. and J.-P. Saucier. 1998. Paysages régionaux du Québec méridional. Les Publications du Québec, Sainte-Foy. 213 pp. Salas González, R., F. Houllier, B. Lemoine and J.C. Pierrat. 1993. Représentativité locale des placettes d'inventaire en vue de l'estimation de variables dendrométriques de peuplement. Ann. Sci. For. 50: 469-485. SAS Institute, Inc. 2000. SAS user's guide: statistics. SAS Institute Inc., Cary, N.C.

Sharma, M., R.L. Amateis and H.E. Burkhart. 2002. Top height definition and its effect on site index determination in thinned and unthinned loblolly pine plantations. For. Ecol. Manage. 168: 163-175.

Turbis, S., D. Mailly and D. Pothier. 2002. ADAGE: un logiciel d'analyse et de description de placettes d'inventaire forestier. Note de Recherche Forestière No. 116, Direction de la recherche forestière, Ministère des Ressources naturelles (Québec). 12 p.

Zeide, B. and W.T. Zakrzewski. 1993. Selection of site trees: the combined method and its application. Can. J. For. Res. 23: 1019-1025. 